\title{
SYNTAXONOMY OF THE ROCKY GRASSLANDS ON CARBONATE BEDROCKS IN THE WEST AND SOUTHWEST OF THE REPUBLIC OF MACEDONIA
}

\author{
MATEVSKI, V. ${ }^{1,2} *$ - ČARNI, A. ${ }^{3,4}$ - ĆUŠTEREVSKA, R. ${ }^{1}-$ KOSTADINOVSKI, M. ${ }^{1}-$ MUCINA, L. ${ }^{5,6,7}$ \\ ${ }^{1}$ Institute of Biology, Faculty of Natural Sciences and Mathematics, University of Ss. Cyril and \\ Methodius, Arhimedova 3, 1000 Skopje, Republic of Macedonia \\ ${ }^{2}$ Macedonian Academy of Sciences and Arts, Bul. Krste Misirkov 2, 1000 Skopje, Republic of \\ Macedonia \\ ${ }^{3}$ Institute of Biology, Scientific Research Centre of the Slovenian Academy of Sciences and Arts, \\ Novi trg 2,1000 Ljubljana, Slovenia; ${ }^{4}$ University of Nova Gorica, Vipavska 13, 5000 Nova \\ Gorica, Slovenia \\ ${ }^{5}$ Iluka Chair, School of Plant Biology, The University of Western Australia, 35 Stirling Hwy, \\ Crawley 6009, Perth, Australia; ${ }^{6}$ Department of Geography \& Environmental Studies, \\ Stellenbosch University, Private Bag X1, Matieland 7602, Stellenbosch, South Africa; \\ ${ }^{7}$ Department of Botany and Microbiology, College of Science, King Saud University, P.O. Box \\ 2455, Riyadh 11451, Saudi Arabia \\ *Corresponding author \\ e-mail:vladom@pmf.ukim.mk \\ (Received $12^{\text {th }}$ Jul 2014; accepted $21^{\text {st }}$ Jan 2015)
}

\begin{abstract}
We classify and describe plant communities of rocky dry grasslands on carbonate bedrock in the southwestern regions of the Republic of Macedonia. We used our own field data and literature sources to compile a set of vegetation plots that have been stored in a vegetation database, data-mined and analyzed using numerical-analytical tools such as cluster analysis and ordination. Five distinct vegetation types, here interpreted as associations, were revealed and characterized using floristic composition, ecological conditions, life forms, chorological spectrum, and topological attributes. Four associations, namely the Petrorhagio haynaldianae-Chrysopogonetum grylli, the Scorzonero-Stipetum endotrichae, the Globulario-Centaureetum grbavacensis and the Astragalo-Helianthemetum marmorei, were recognized as new. All these associations belong to the Saturejo-Thymion (Astragalo-Potentilletalia, FestucoBrometea).
\end{abstract}

Keywords: Balkan Peninsula, dry grasslands, Festuco-Brometea, syntaxonomy, vegetation classification

\section{Introduction}

Dry grasslands are one of the most endangered habitats in Europe (Janišová et al., 2011; Vassilev et al., 2011) due to changes of traditional grassland management and a number of other threats, such as urban sprawl, afforestation and the like. This vegetation is widespread in the central and southern regions of the Balkan Peninsula, since this region experiences relatively dry and warm climate; grazing has long been in these grasslands an important agricultural activity securing the existence of these grasslands for centuries. Although there have been some older (see below) and more recent (Bergmeier et al., 2009; Aćić et al., 2013; Pedashenko et al., 2013) vegetationclassification studies of the dry grasslands in the central and southern Balkans, our knowledge of their floristic and geographic variability is far from sufficient. 
Micevski (1970, 1971a) initiated the research on the vegetation of dry grasslands in the region. This author classified the dry grasslands on carbonate bedrock into then a new alliance - the Saturejo-Thymion, and a new order - the Astragalo-Potentilletalia. Micevski later described several associations, mainly on silicate bedrocks in Macedonia (Micevski, 1972, 1977, 1978; Micevski and Matevski, 1984). V. Matevski and his collaborators (Matevski and Kostadinovski, 1998; Matevski et al., 2007) published studies from western Macedonia where the dry grasslands are fairly fragmented. More recently, research was carried out in dry grasslands of northern Macedonia on noncarbonate bedrocks (Ćušterevska et al., 2012).

In this study, we aimed to collect all high-quality vegetation-plot data on dry grasslands on calcareous bedrock in southwestern Macedonia and to investigate whether an analysis of this larger data set would recover known vegetation-classification patterns or reveal new syntaxonomic entities.

\section{Materials and methods}

\section{Study area}

We focused on the collection of vegetation plot data in grasslands on carbonate bedrocks the western and southwestern regions of the Republic of Macedonia (Fig. 1); the eastern part of the country is mainly composed of non-carbonate bedrock.

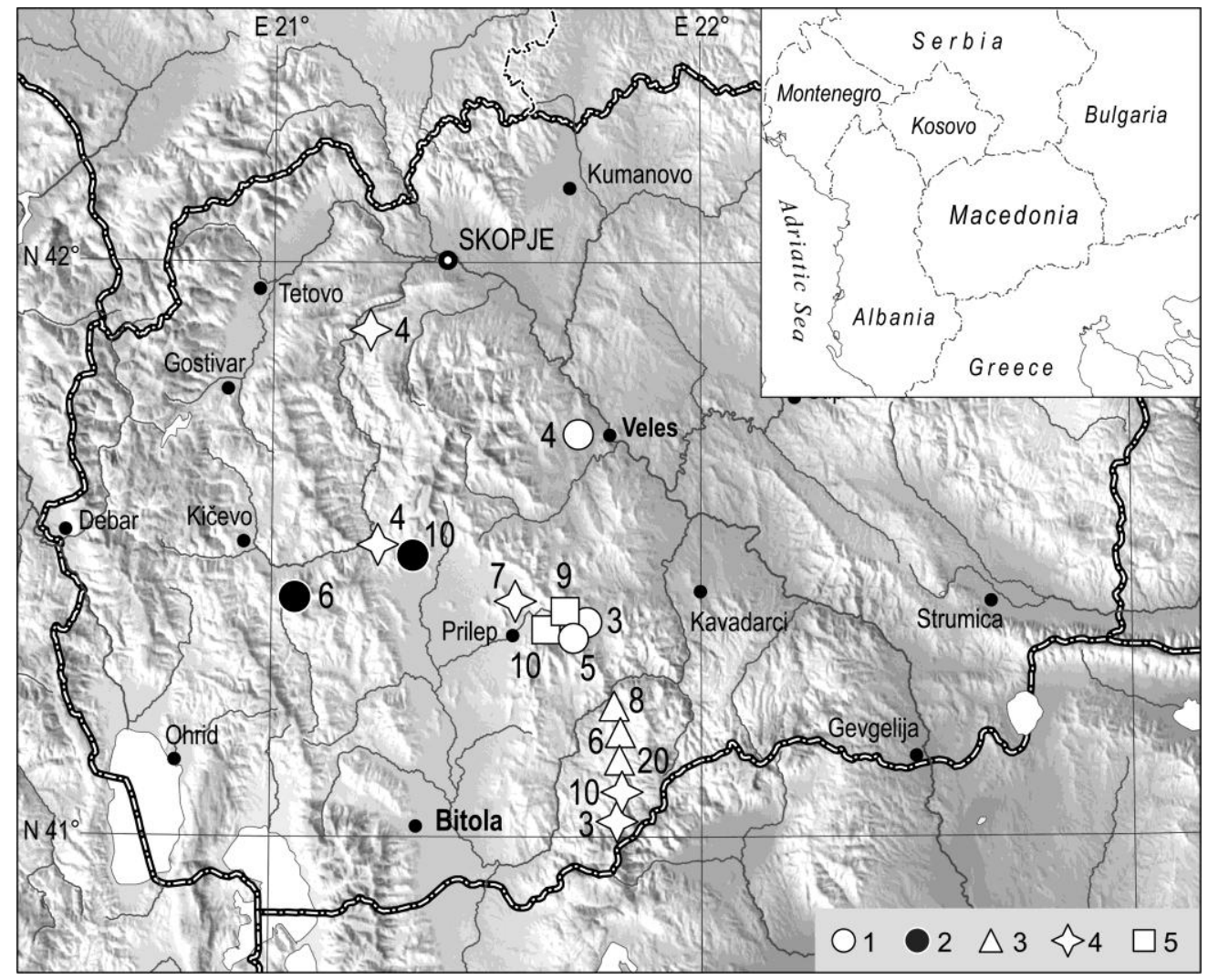

Figure 1. Location of the studied area. 1 - Petrorhagio-Chrysopogonetum grylli, 2 - Sileno-

Thymetum ciliatopubescentis, 3 - Scorzonero-Stipetum endotrichae, 4 - Globulario-

Centaureetum grbavacensis, 5 - Astragalo-Helianthemetum marmorei. Numbers at signs indicate number of relevés made at each locality. 
The dry grasslands here are secondary as they were formed by long-lasting degradation of the original forest vegetation, including oak forests dominated by Quercus pubescens, $Q$. cerris, $Q$. frainetto, $Q$. trojana, and, in places, also by Carpinus orientalis (Rizovski, 1974, 1978; Matevski et al., 2008). The potential natural vegetation of the region could be classified as the Quercetea pubescentis forests (Horvat et al., 1974; Filipovski et al., 1996; Bohn et al 2004, Čarni et al., 2009).

The climate of the region has submediterranean character, with a pronounced dry summer season. Prilep, situated in the center of the study area, has a mean annual precipitation of $557 \mathrm{~mm}$ (most of the rainfall is concentrated to May and November) and mean annual temperature of $11.2^{\circ} \mathrm{C}$. The sampled grasslands occurred at altitudes ranging from $540 \mathrm{~m}$ to $1300 \mathrm{~m}$.

\section{Vegetation sampling}

Original vegetation plot data were collected according to the standard BraunBlanquet method of field-plot sampling (Braun-Blanquet, 1964). The sampling was done during the optimal phenological period of the year - from the second half of May to mid-June. The size of the sampled plots was $100 \mathrm{~m}^{2}$. The choice of this sample size was motivated by the relatively homogenous vegetation at this scale and the preponderance of vegetation plot data collected at that scale in the past. The plots were located within targeted remnant patches of dry grasslands in such a way that edge effects (close forest edge, roads, and settlements) were excluded.

\section{Data analysis}

The sampled 109 relevés were entered into TURBOVEG (Hennekens and Schaminée, 2001). Classification was made using the PC-ORD 4 package (McCune and Mefford, 1999) integrated in JUICE software, using Ward's method (clustering) and Relative Euclidean Distance (known also as Chord Distance) as the measure of resemblance among relevés. The table sorting based on this clustering was then performed in JUICE 7.0 (Tichý and Holt, 2006). Diagnostic species of each cluster (interpreted as associations) were defined in JUICE by calculating the fidelity of each species to each group using the phi coefficient as the fidelity measure (Chytrý et al., 2002). The threshold of the phi value was selected at level 0.55. Diagnostic, constant, and dominant species were identified by JUICE (see the descriptions of the plant communities); the diagnostic species were recognised using the the phi coefficient greater than 0.55 (those more than 0.90 as highly diagnostic in the list of the diagnostic species in the description of the identified associations are given in bold); the constant species occur in $90 \%$ of relevés (those occurring in $100 \%$ of the relevés are also given in bold) while the dominant species are those having cover of the category 4 and 5 of the original Braun-Blanquet scale.

We have ordinated the species $\mathrm{X}$ relevé matrix using non-metric multidimensional scaling (NMDS), using Mass package (Venables and Ripley, 2002) in R version 2.13 software (http://www.r-project.org/), based on Relative Euclidean Distance. Cover values were transformed to mean cover percentage and square rooted. In order to assist ecological interpretation of the ordinated patterns, average bioindicator values (Pignatti, 2005) for the relevés were calculated based on presence-absence data and overlaid as supplementary environmental data. 
We used Raunkiaer's (1934) system of life forms and we determined the chorological spectra using data of Gajić (1980) and Pignatti (2005). The chorological spectrum is presented as percentages of each group of species within the entire species composition. Box-whiskers diagrams of altitude and slope are also presented in order to document differences between clusters (associations); these were calculated in Statistica (STATSOFT, 2007).

The analytic table presents the results of the cluster analysis and subsequent JUICE tabular sorting. The syntaxonomic affiliation of taxa other than diagnostic ones was decided upon using expert knowledge and the unpublished database of the European Vegetation Checklist (L. Mucina et al., in prep.). Species with low frequency in the analytical table, as well as relevant locality and sampling metadata on each relevé, are listed in the Appendix.

The nomenclature follows in principle the Flora Europaea (Tutin et al., 1964-1993) however it was adjusted using the Med-Check List (Greuter et al., 1984-1989; Greuter et al., 2008) and new taxonomic and nomenclatural findings as featured in the Euro+Med Database (www.emplantbase.org). Some taxonomic concepts follow regional floras (Hayek, 1927, 1931, 1933; Micevski, 1985-2005; Matevski, 2010; Josifović, 1970-1986; Jordanov, 1963-1979; Velchev, 1982-1989; Kozuharov, 1995). Formation of the names of the new syntaxa follows the International Code of Phytosociological Nomenclature (Weber et al., 2000).

\section{Results and discussion}

\section{Major vegetation patterns}

The cluster analysis suggested five well separated clusters (Fig. 2). Since they show a high degree of floristic (and geographic) integrity, they are interpreted as associations (Elect. App.), such as the Petrorhagio-Chrysopogonetum grylli (Cluster 1), the SilenoThymetum ciliatopubescentis (Cluster 2), the Scorzonero-Stipetum endotrichae (Cluster 3 ), the Globulario-Centaureetum grbavacensis (Cluster 4), and the AstragaloHelianthemetum marmorei (Cluster 5).

NMDS with passively projected bioindicator values (Fig. 3) illustrates the ecological differences between the associations. The Sileno-Thymetum ciliatopubescens is typically found on the wet extreme of the moisture gradient revealed along the axis 1 of NMDS. This community is found in the westernmost, precipitation-richest region of the studied area. The Scorzonero-Stipetum endotrichae is found in habitats in the southern part of the area. The stands of the Globulario-Centaureetum grbavacensis are typically found in disturbed habitats where the bedrock shows possibly the greatest influence on the floristic composition. The Petrorhagio-Chrysopogonetum grylli and SilenoThymetum ciliatopubescentis can be found at winter-mild low altitudes, whereas the Scorzonero-Stipetum endotrichae, the Globulario-Centaureetum grbavacensis and the Astragalo-Helianthemetum marmorei are confined to higher altitudes characterized by climatic extremes such as pronounced continentality.

The life-form analysis (Fig. 4) revealed that the Petrorhagio-Chrysopogonetum grylli and the Sileno-Thymetum ciliatopubescentis are richer in therophytes and are found in lowlands as is the Scorzonero-Stipetum endotrichae found in the southern part of the studied area. Hemicryptophytes prevail in the dry grassland communities confined to the high altitudes in the central part of the study area (GlobularioCentaureetum grbavacensis and Astragalo-Helianthemetum marmorei). 


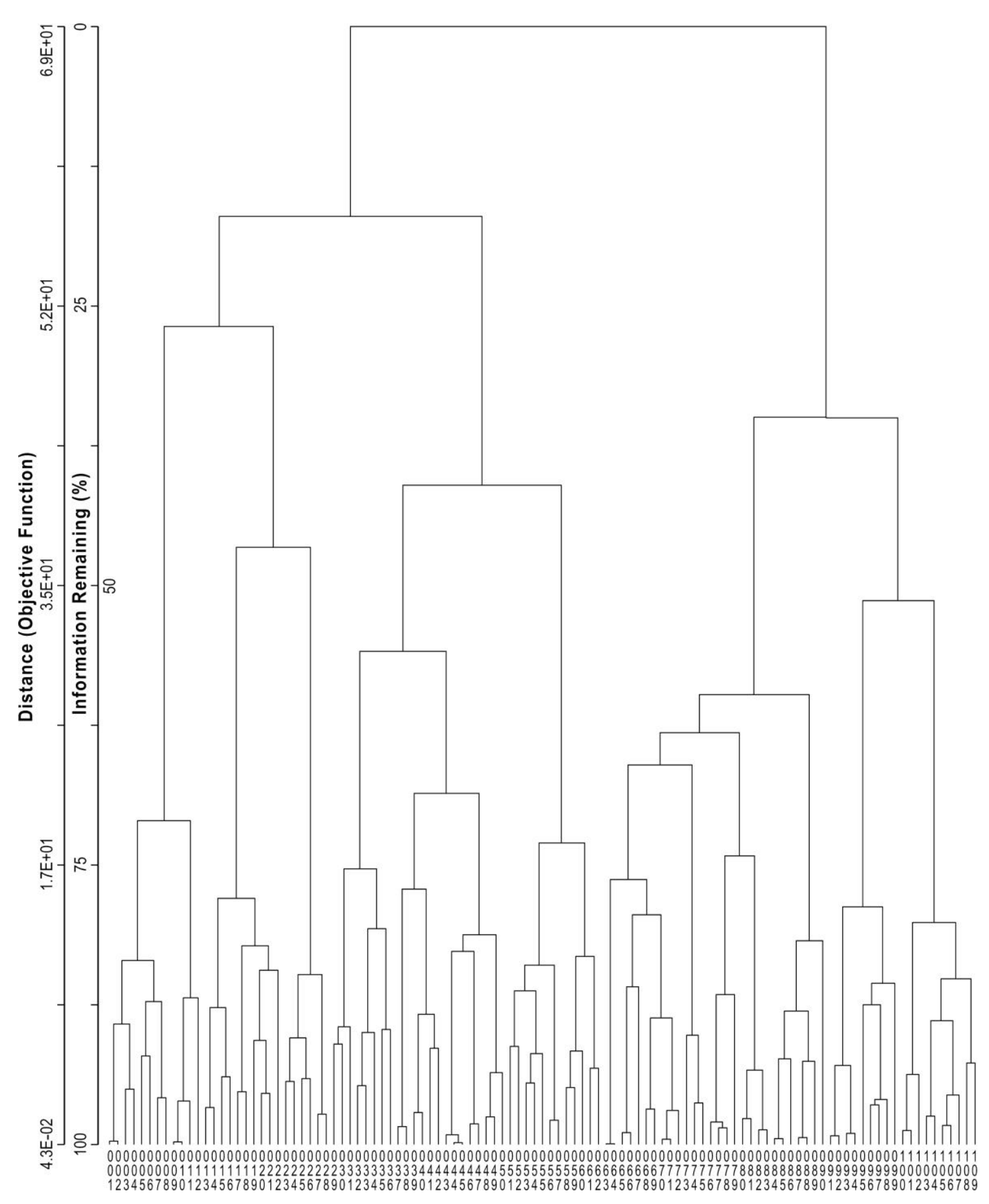

Figure 2. Classification of the studied dry grasslands (Ward's clustering method, relative Euclidean distance). Legende: Cluster 1 (rels. 1-12): Petrorhagio - Chrysopogonetum grylli,

Cluster 2 (rels. 13-28): Sileno-Thymetum ciliatopubescentis, Cluster 3 (rel. 29-62):

Scorzonero-Stipetum endotrichae, Cluster 4 (rels. 63-90): Globulario-Centaureetum grbavacensis, Cluster 5 (rels. 91-109): Astragalo-Helianthemetum marmorei.

The results of chorological analysis are shown in Fig. 5. Balkan and Sub-Balkan geo-elements are dominant in all associations. Most Balkan and South-European orophytes can be found at high altitudes in the central part of the studied area (Globulario-Centaureetum grbavacensis and Astragalo-Helianthemetum marmorei) 
whereas Euri-Mediterranean and Eurasian species are more common at lower altitudes and in the southern regions (Petrorhagio-Chrysopogonetum grylli, Sileno-Thymetum ciliatopubescentis and Scorzonero-Stipetum endotrichae). Steno-Mediterranean species are most common in the Petrorhagio-Chrysopogonetum grylli occurring at the lowest altitudes of all dry grasslands studied.

Fig. 6. focuses on the Balkan and Sub-Balkan geo-elements. Species of the former two geoelements are most common at higher altitudes in the central regions of the studied area (Globulario-Centaureetum grbavacensis, Astragalo-Helianthemetum marmorei), while many South-Balkan species can also be found here in degraded habitats - in the Globulario-Centaureetum grbavacensis. A high proportion of ScardoPindian elements can be found in the Scorzonero-Stipetum endotrichae at higher altitudes in the south of the region.

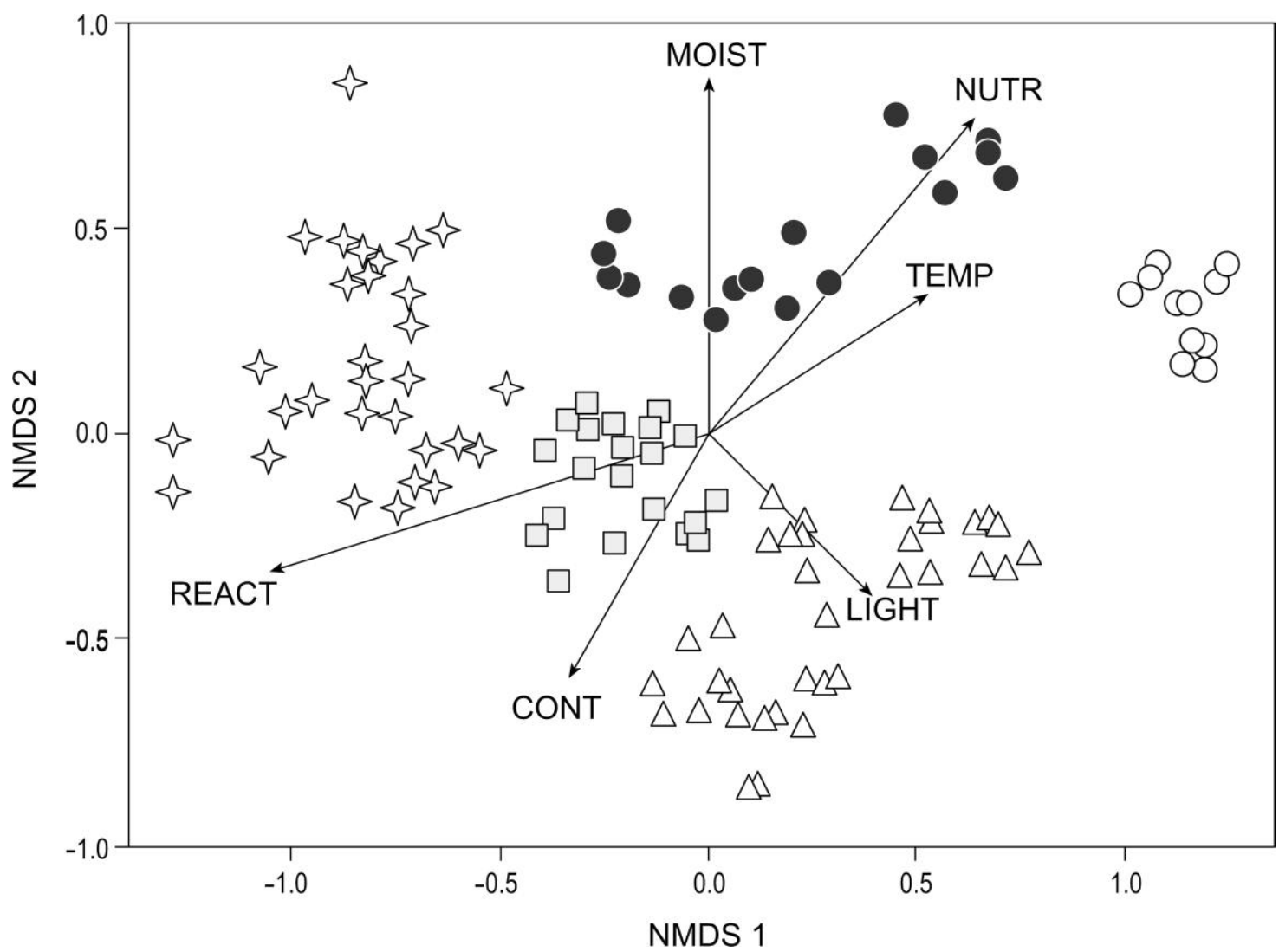

Figure 3. NMDS ordination (axes 1 and 2) based on relative Euclidean distance, with passive projection of bioindicator values for 5 communities. $\circ$ Petrorhagio-Chrysopogonetum grylli;

Sileno-Thymetum ciliatopubescentis; $\Delta$ Scorzonero-Stipetum endotrichae; \& GlobularioCentaureetum grbavacensis; $\square$ Astragalo-Helianthemetum marmorei.

The Petrorhagio-Chrysopogonetum grylli and the Sileno-Thymetum ciliatopubescentis are found on moderate slopes (Fig. 7), while the Scorzonero-Stipetum endotrichae, the Globulario-Centaureetum grbavacensis and the AstragaloHelianthemetum marmorei are confined to steeper slopes. No significant differences between communities were found in relation to aspect of the slope (data not shown). 


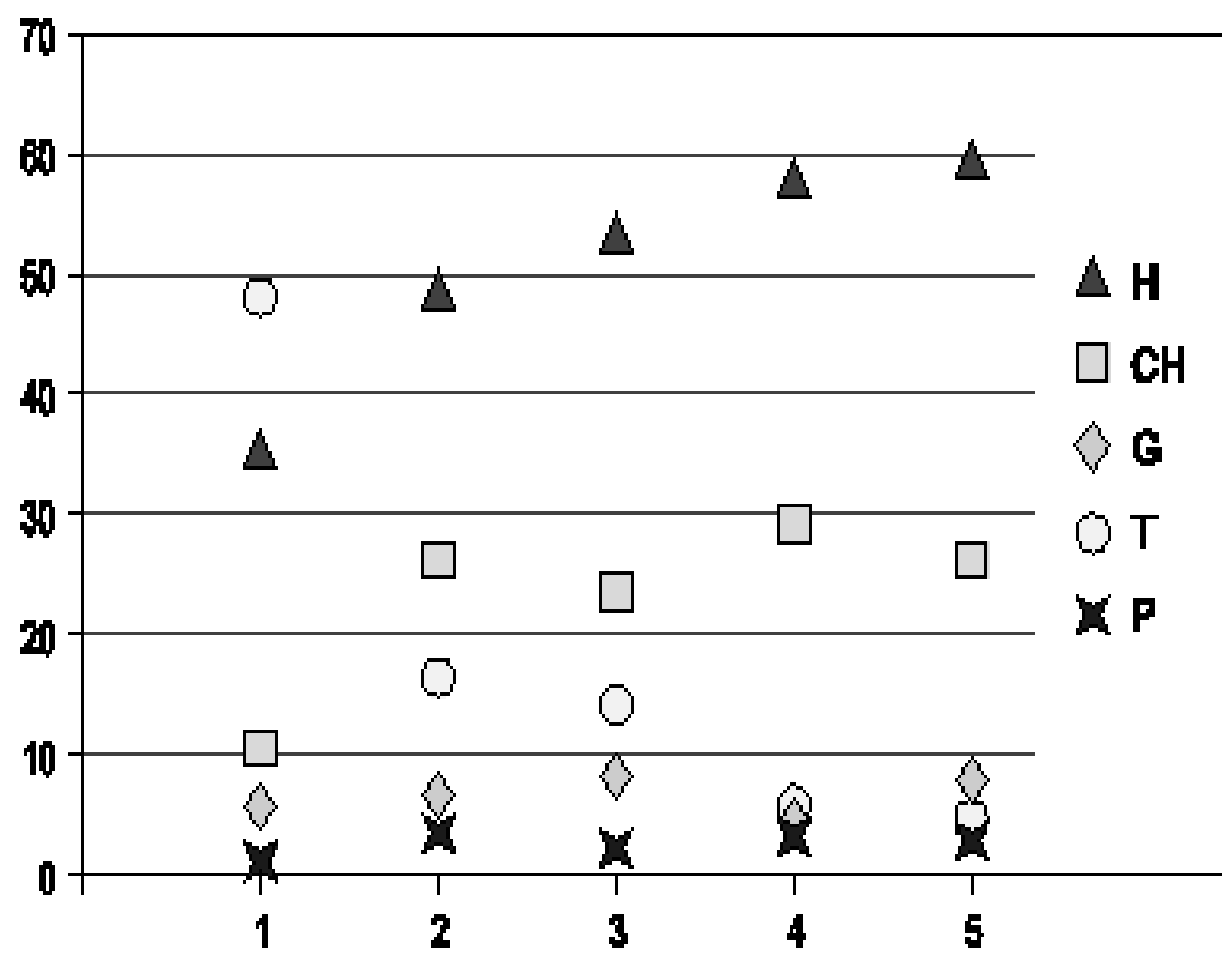

Figure 4. Life-form spectra. The numbering of clusters corresponds to that in Fig. 2. G: geophytes, Ch: chamaephytes, $H$ : hemicryptophytes, $P$ : phanerophytes, $T$ : therophytes.

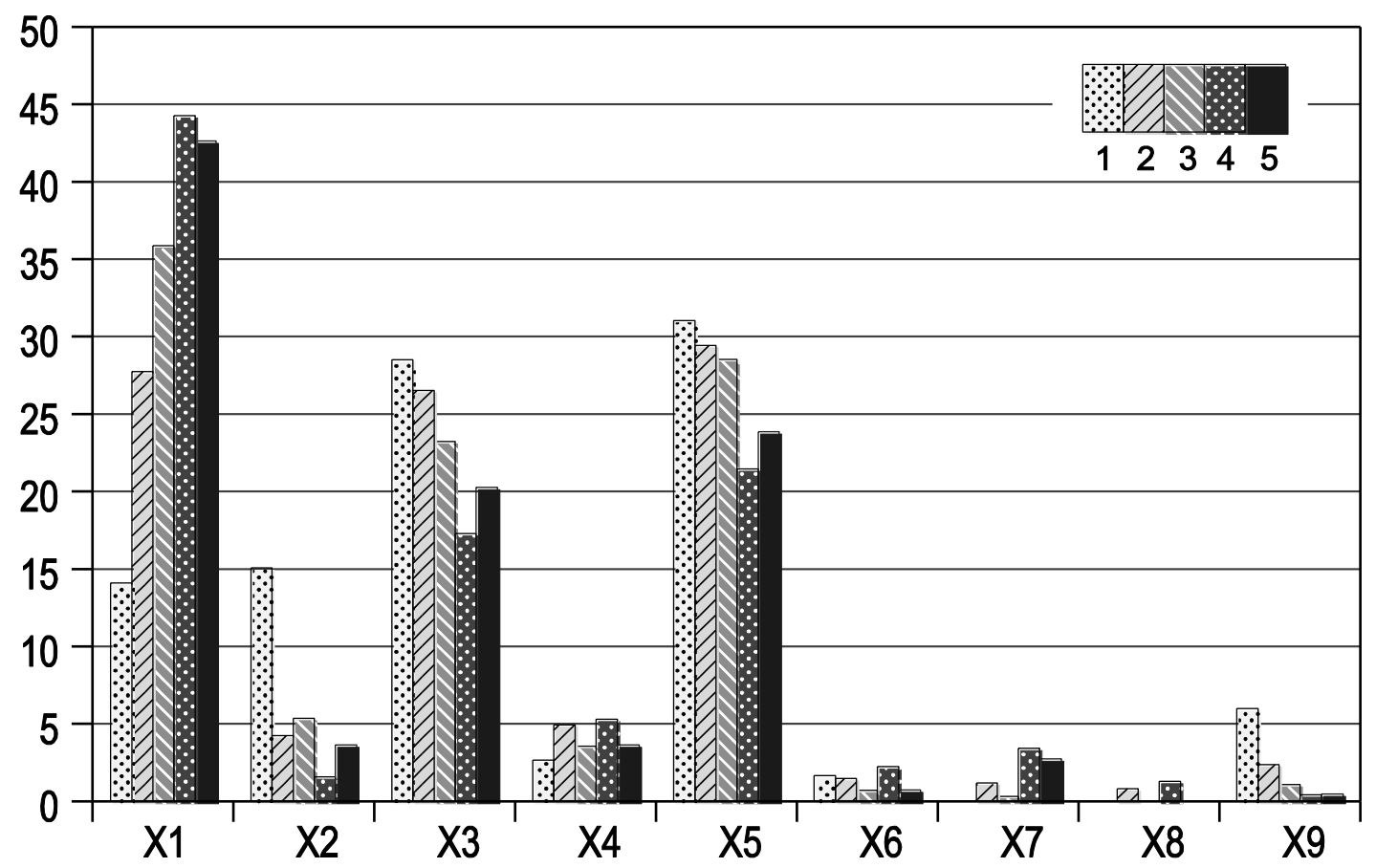

Figure 5. General chorological spectra. The numbering of clusters corresponds to that in Fig.

2. Geoelements: X1: Balkan, X2: Steno-Mediterranean, X3: Eury-Mediterranean, X4:

Mediterranean-montane, X5: Eurasian, X6: Atlantic, X7: Orophilous South-European, X8: Boreal, X9: Cosmopolitan. 


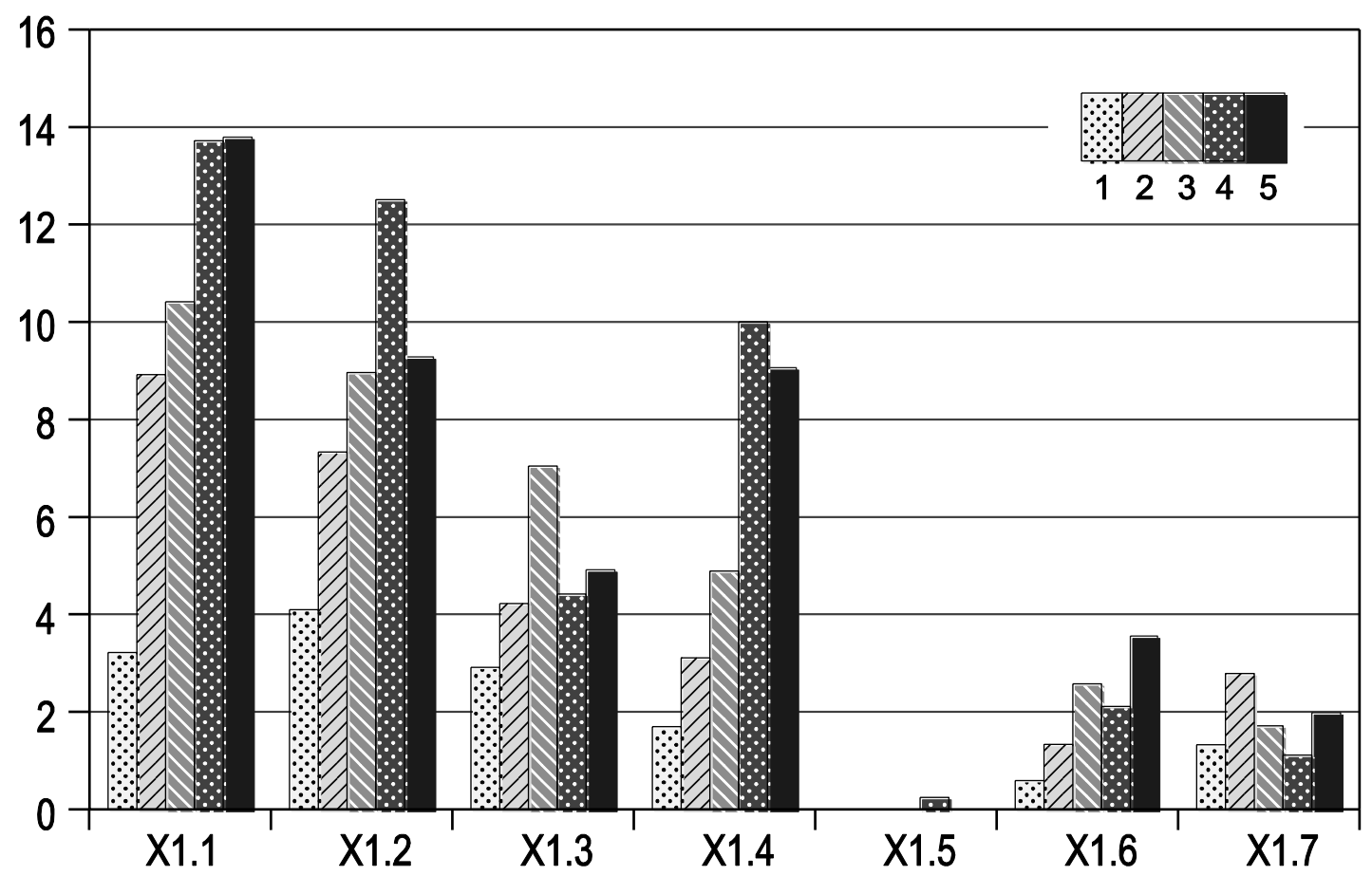

Figure 6. Chorological spectra the Balkan and Sub-Balkan elements. The numbering of clusters corresponds to that in Fig. 2. X1.1: Balkan (sensu lato), X1.2: South Balkan, X1.3: ScardoPindian, X1.4: Macedonian (sub) endemic, X1.5: Balkan-Apennine, X1.6: South Balkan-Asia Minor, X1.7: South Balkan-Caucasian.

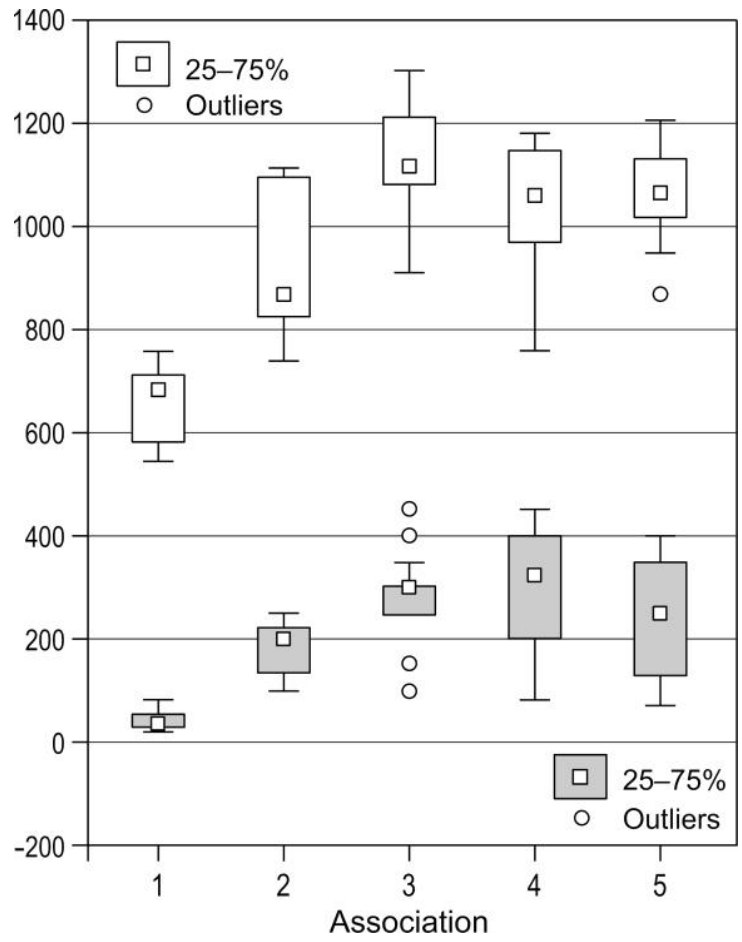

Figure 7. Altitudinal (empty boxes) and slope (shaded boxes) profiles for the studied communities. The numbering of clusters corresponds to that in Fig. 2. The upper case present altitude and lower slope. 
The comparison of these syntaxonomic units with the existing relevant literature revealed that all associations, except for the Sileno-Thymetum ciliatopubescentis Matevski et al. 2007, should be described as new.

Petrorhagio haynaldianae-Chrysopogonetum grylli Matevski, Čarni, Ċušterevska, Kostadinovski et Mucina ass. nova hoc loco

Holotypus hoc loco: Elect. App., relevé 1; the relevé is presented in the printed Appendix at the end of this paper.

Diagnostic species: Achillea coarctata, Aegilops neglecta, Ajuga chamaepitys subsp. chia, Alyssum simplex, Arenaria serpyllifolia, Astragalus onobrychis, Bombycilaena erecta, Bothriochloa ischaemum, Bromus squarrosus, Bupleurum apiculatum, Carduus nutans, Centaurea stoebe subsp. australis, Cerastium glomeratum, Chrysopogon gryllus, Clinopodium suaveolens, Clypeola jonthlaspi, Convolvulus canthabrica, Crepis sancta, Crucianella graeca, Crupina vulgaris, Dasypyrum villosum, Echinops sphaerocephalus, Euphorbia taurinensis, Festuca callieri, Galium verticillatum, Helianthemum salicifolium, Hippocrepis ciliata, Linaria simplex, Linum corymbulosum, Medicago coronata, Medicago glomerata, Medicago minima, Medicago rigidula, Micromeria juliana, Minuartia glomerata subsp. glomerata, Minuartia hamata, Minuartia hybrida, Nigella arvensis, Onobrychis aequidentata, Ononis reclinata, Orlaya daucorlaya, Parentucellia latifolia, Petrorhagia illyrica subsp. haynaldiana, Petrorhagia prolifera, Picris pauciflora, Potentilla pedata, Psilurus incurvus, Sanguisorba minor, Satureja montana subsp. pisidica, Scabiosa divaricata, Sherardia arvensis, Sideritis montana, Silene radicosa, Stipa pennata, Thymus striatus, Trachynia distachya, Tragopogon dubius, Trifolium campestre, Trifolium scabrum, Trigonella gladiata, Trigonella monspeliaca, Valerianella dentata, Velezia rigida, Veronica arvensis, Xeranthemum annuum, Ziziphora capitata

Constant species: Eryngium campestre, Euphorbia myrsinites, Hypericum rumeliacum, Koeleria splendens, Leontodon crispus, Melica ciliata, Ornithogalum comosum, Poa bulbosa, Potentilla astracanica, Sedum urvillei, Teucrium capitatum

Dominant species: Chrysopogon gryllus

Distribution: central part of the Republic of Macedonia (surroundings of Veles, Negotino and Prilep)

This community develops on deeper soils in sunny, slightly inclined habitats, at altitudes of 120-550 (750) $\mathrm{m}$. There are various opinions about the floristic diversity and syntaxonomic affiliation of the Chrysopogon gryllus-dominated communities in the Balkans (Kojić 1955, 1957, 1959; Ilijanić and Topić, 1989; Bergmeier et al., 2009). In the continental parts of the Balkan Peninsula, situated more to the north and east of our study area (in Serbia and Bulgaria), the communities in which Chrysopogon gryllus appears as dominant are classified within the Chrysopogono-Danthonion Kojić 1957, the Festucetalia valesiacae (Horvat et. al., 1974; Kojić et al., 1998; Jovanović et al., 1986; Redžić, 1999; Meshinev et al., 2005). Bergmeier et al. (2009) suggested that the syntaxonomic position of the Chrysopogono-Danthonion within the AstragaloPotentilletalia is more acceptable than within the Festucetalia valesiacae (FestucoBrometea). It may also well be that the Chrysopogono-Danthonion does not belong to the Festuco-Brometea, but should rather be classified within the KoelerioCorynephoretea. 
We suggest that the Petrorhagio-Chrysopogonetum grylli belongs to the SaturejoThymion (Astragalo-Potentilletalia, Festuco-Brometea). It cannot be classified within the Chrysopogono-Danthonion since most of the taxa typical of the ChrysopogonoDanthonion (Danthonia alpina, Achillea chrysocoma, Silene bupleuroides subsp. staticifolia, Trifolium montanum, Trifolium ochroleucon, Luzula campestris, Leucanthemum vulgare etc.) are found on nutrient-poor (non-carbonate) soils and in Macedonia they rather prefer higher altitudes.

The Petrorhagio-Chrysopogonetum grylli represents a therophytic-hemicryptophytic community, whereas other communities of dry grasslands from the southwestern Macedonia on carbonate bedrocks are of chamaephytic-hemicryptophytic character. A larger proportion of Steno-Mediterranean and Eury-Mediterranean species can be found in this community (Fig. 5), and the number of Balkan, South-Balkan, Scardo-Pindian and endemic Macedonian species (Fig. 6) is lower than in the other studied dry grassland communities. The Petrorhagio-Chrysopogonetum grylli, limited to region of pronounced sub-mediterranean climate which expands to the Central Balkans along the valley of the Vardar River.

Scorzonero-Stipetum endotrichae Matevski, Čarni, Cušterevska, Kostadinovski et Mucina ass. nova hoc loco

Holotypus hoc loco: Elect. App., relevé 54; the relevé is presented in the printed Appendix at the end of this paper.

Distribution: Republic of Macedonia (Mariovo: Crna Reka Gorge, Vitolishte, Zivovo, Beshishte)

Diagnostic species: Astragalus mariovoense, Helianthemum canum, Helianthemum nummularium subsp. numummularium, Helictochloa aetolica, Hellenocarum strictum, Leontodon biscutellifolius, Minuartia verna subsp. collina, Scorzonera mariovoensis, Sedum acre, Sideritis raeseri, Stipa endotricha, Thymus parnassicus, Trinia daleschampii, Veronica praecox

Constant species: Agropyron cristatum, Eryngium campestre, Festuca hirtovaginata, Hypericum rumeliacum, Koeleria splendens, Potentilla astracanica, Scabiosa triniifolia, Stachys iva, Teucrium capitatum

Dominant species: Inula aschersoniana

This community is found in rocky (marble) steep slopes, with very shallow layer of soil at altitudes spanning 900-1280 m. The region of the occurrence of this dry grassland type is a sub-mediterranean oasis located along the course of the river Crna Reka. This community is home of several Macedonian endemic species such as Astragalus mariovoense, Stachys iva and Scorzonera mariovoensis. The surrounding forest vegetation is dominated by Macedonian oak forests (Quercetum trojanae) and hornbeam forests of the Phyllireo-Carpinetum orientalis (Fraxino Ostryion, Quercetalia pubescentis).

Globulario-Centaureetum grbavacensis Matevski, Čarni, Ċušterevska, Kostadinovski et Mucina ass. nova hoc loco

Holotypus hoc loco: Elect. App., relevé 83; the relevé is presented in the printed Appendix at the end of this paper. 
Diagnostic species: Anthericum ramosum, Centaurea grbavacensis, Globularia cordifolia, Matthiola fruticulosa subsp. vallesiaca, Paronychia chionea, Saxifraga federici-augusti subsp. grisebachii, Scorzonera austriaca, Viola herzogii

Constant species: Fumana procumbens, Juniperus oxycedrus

Dominant species: Anthyllis aurea, Centaurea grbavacensis

Distribution: Republic of Macedonia (surroundings of Prilep-Kozjak, Sivec, Debreshte, M. Brod-Barbaras, Mariovo-Sekulova Tumba, Labinica, Toplik, SkopjeNova Breznica)

This community is found typically on dolomitised limestone at altitudes between 800 and $1180 \mathrm{~m}$, on relatively steep slopes spanning $15^{\circ}$ and $45^{\circ}$. The best example of this vegetation can be found in habitats formerly occupied by the Macedonian oak forests (Quercetum trojanae) or those previously dominated by Pinus nigra (Fago-Pinetum nigrae). The Macedonian (sub) endemic taxa, Centaurea grbavacensis and Viola herzogi, are of particular importance in this community.

Astragalo-Helianthemetum marmorei Matevski, Čarni, Ċušterevska, Kostadinovski et Mucina ass. nova hoc loco

Holotypus hoc loco: Elect. App., relevé 103; the relevé is presented in the printed Appendix at the end of this paper.

Diagnostic species: Achillea agaretifolia subsp. aizoon, Allium bornmulleri, Asperula purpurea, Astragalus sericophyllus, Bromopsis riparia, Helianthemum marmoreum, Helianthemum nummularium subsp. tomentosum, Hyssopus officinalis subsp. aristatus, Linum austriacum, Medicago prostrata, Micromeria cristata subsp. kosaninii, Minuartia setacea, Odontites glutinosa, Phelypaea boissieri, Polygala vulgaris, Trinia glauca

Constant species: Agropyron cristatum, Alyssum corymbosoides, Anthyllis aurea, Asperula aristata subsp. scabra, Asyneuma limonifolium, Carex liparocarpos, Centaurea grbavacensis, Clinopodium alpinum subsp. hungaricum, Dianthus haematocalyx, Festuca hirtovaginata, Fumana procumbens, Galium oreophilum, Hypericum rumeliacum, Iris pumila, Jurinea polycephala, Koeleria splendens, Leontodon crispus, Melica ciliata, Ornithogalum comosum, Potentilla astracanica, Scabiosa triniifolia, Sedum ochroleucum, Sedum urvillei, Stachys iva, Stipa pulcherrima, Teucrium capitatum, Teucrium montanum, Thymus parnassicus, Vincetoxicum hirundinaria subsp. nivale, Viola herzogii

Dominant species: Centaurea grbavacensis

Distribution: Republic of Macedonia (surroundings of Prilep-Kozjak, Pletvar, Raec Reka)

This community develops on dolomitised limestone at altitudes spanning 950-1200 $\mathrm{m}$, on slopes $7^{\circ}-25^{\circ}$ (sometimes up to $40^{\circ}$ ) steep. It is a very thermophilous grassland supporting several (sub)endemics including Astragalus sericophyllus, Helianthemum marmoreum, Seseli vandasii and Stachys iva.

Sileno-Thymetum ciliatopubescentis Matevski et al. 2007

Distribution: Republic of Macedonia (around Prilep: Debreška Krasta; below mountain Baba Sač: Cer; Kičevsko). 
The Sileno-Thymetum ciliatopubescentis has already been formally described by Matevski et al. (2007). This community develops on carbonate bedrocks at altitudes of $700-1100 \mathrm{~m}$. The stands of this association are found in the nutrient-richest and moisture-supplied habitats of all the communities concerned. This vegetation is found at relatively low altitudes and therefore is considerably thermophilous.

\section{Syntaxonomic conclusions}

The dry grasslands on carbonate bedrocks in the Republic of Macedonia belong to the Saturejo-Thymion (Micevski, 1970, 1971a, 1971b; Matevski el al., 2007). The syntaxonomically regionally important taxa of the Saturejo-Thymion include Agropyron cristatum, Anthyllis vulneraria subsp. rubriflora, Carex liparocarpos, Dianthus haematocalyx subsp. haematocalyx, Dianthus kapinaensis, Genista sessilifolia, Potentilla astracanica, Silene radicosa, Stachys iva, Thymus parnassicus, T.. skopjensis, Viola herzogii, and others. They are calcicolous elements, and many are endemic to Macedonia or to the Central Balkans.

The grasslands of the Saturejo-Thymion cover extensive areas throughout the Republic of Macedonia, especially in northern, western, southwestern and central regions of the country as well as in northern Greece (Bergmeier et al., 2009). They are of secondary origin and are a result of the destruction and degradation of various zonal forest communities, such as the Phillireo-Carpinetum orientalis, the Quercetum trojanae, the Quercetum frainetto-cerris and the like (Micevski, 1971; Matevski et al., 2007).

Acknowledgements. We owe thanks to Iztok Sajko, who kindly prepared the map and other figures. This paper is a result of various projects funded by the Ministry of Education and Science of the Republic of Macedonia, as well as bilateral projects between Macedonia and Slovenia, financed by the Ministry of Education and Science of the Republic of Macedonia and the Slovenian Research Agency (P1-0236). LM acknowledges the logistic support of the Iluka Chair, The University of Western Australia.

\section{REFERENCES}

[1] Aćić, S., Šilc, U., Vrbničanin, S., Cupać, S., Topisirović, G., Stavretović N., DajićStevanović, Z. (2013): Grassland communities of Stol Mountain (Eastern Serbia): vegetation and environmental relationships. - Archives of Biological Sciences 65: 211227.

[2] Bergmeier, E., Konstantinou, M., Tsiripidis, I., Sýkora, V. (2009): Plant communities on metalliferous soils in northern Greece. - Phytocoenologia 39: 411-438.

[3] Bohn,U.,Gollub,G., Hettwer,C., Neuhäuslová.Z., Raus.T., Schlüter. H., et al (2004): Karte der natürlichen Vegetation Europas/Map of the natural vegetation of Europe. BonnBad Godesberg, Germany: BfN. CD-ROM.

[4] Braun-Blanquet, J. (1964): Pflanzensoziologie. Grundzüge der Vegetationskunde. 3. Aufl. - Springer Verlag, Wien.

[5] Chytrý, M., Tichý, L., Holt, J., Botta-Dukát, Z. (2002): Determination of diagnostic species with statistical fidelity measures. - Journal of Vegetation Science 13: 79-90.

[6] Čarni, A., Košir, P., Karadžić, B., Matevski, V., Redžić, S., Škvorc, Ž. (2009): Theromophilous deciduous forests in Southeastern Europe. - Plant Biosystems 143: 113. 
[7] Ćušterevska, R., Matevski, V., Kostadinovski, M., Čarni, A. (2012): Dry grasslands communities of Erysimo-Trifolietum in the north-eastern part of the Republic of Macedonia. - Hacquetia 11: 91-111.

[8] Filipovski, G., Rizovski, R., Ristevski, P. (1996): Karakteristiki klimatsko-vegetaciskopočvenite zoni (regioni) bo Republika Makedonija. - Macedonian Academy of Sciences and Arts, Skopje.

[9] Gajić, M. (1980): Pregled vrsta flore S.R. Srbije sa biljno-geografskim oznakama. Glasnik Šumarskog Fakulteta, Šumarstvo 54: 111-140.

[10] Greuter, W., Burdet, H.M., Long, G. (ed.) (1984-1989): Med-Checklist. 1, 3, 4. Conservatoire et Jardin Botanique de la Ville de Genève, Genève.

[11] Greuter, W, Burdet, H.M., Long, G. (eds.) (2008): Med-Checklist 2. - Optima Secretariat, Palermo; Med-Check Trust of Optima, Genève; Euro+Med Plantbase Secretariat, Berlin.

[12] Hayek, A. (1927): Prodromus florae peninsulae Balcanicae. I. - Repertorium specierum novarum regni vegetabilis 30 (1). - Verlag des Repertoriums, Dahlem bei Berlin.

[13] Hayek, A. (1931): Prodromus florae peninsulae Balcanicae. I. - Repertorium specierum novarum regni vegetabilis 30 (2). - Verlag des Repertoriums, Dahlem bei Berlin.

[14] Hayek, A. (1933): Prodromus florae peninsulae Balcanicae. I. - Repertorium specierum novarum regni vegetabilis 30 (3). - Verlag des Repertoriums, Dahlem bei Berlin.

[15] Hennekens, S.M., Schaminée, J.H.J. (2001): TURBOVEG, a comprehensive database management system for vegetation data. - Journal of Vegetation Science 12: 589-591.

[16] Horvat, I., Glavač, V., Ellenberg, H. (1974): Vegetation Südosteuropas. - Gustav Fischer Verlag, Stuttgart.

[17] Ilijanić, L., Topić, J. (1989): On the sociology of Chrysopogon gryllus in Yugoslavia. Acta Botanica Croatica 48: 75-82.

[18] Janišová, M., Wellstein, C., Willner, W., Dengler, J. (2011): Succession, restoration, and management of dry grasslands. - Tuexenia 31: 227-234.

[19] Jordanov, D. (ed.) (1963-1979): Flora Reipublicae Popularis Bulgaricae. Vols. 1-7. - In Aedibus Academiae Scientarum Bulgaricae, Serdicae (Sofia).

[20] Josifović, M. (ed.) (1970-1986): Flora SR Srbije, Vol. 1-10. - Serbian Academy of Science and Arts, Beograd.

[21] Jovanović, B., Lakušić, R., Rizovski, R., Trinajstić, I., Zupančič, M. (1986): Prodromus phytocenosum Yugoslaviae ad mappam vegetationis 1: 200 000. - Naučno veće vegetacijske karte Jugoslavije, Bribir-Ilok.

[22] Kojić, M. (1955): O fitocenozi đipovine (Chrysopogon gryllus) u Šumadiji. - Zbornik Radova Poljoprivrednog Fakulteta, Zemun 3: 91-98.

[23] Kojić, M. (1957): Chrysopogono-Danthonion calycinae - nova sveza iz reda Festucetalia vallesiacae Br. Bl. et Tx. - Zbornik Radova Poljoprivrednog Fakulteta, Zemun 5: 51-55.

[24] Kojić, M. (1959): Zastupljenost, uloga i značaj djipovine (Chrysopogon gryllus Trin.) u livadskim fitocenozama zapadne Srbije. - Arhiv Poljoprivrednih Nauka, Beograd 46: 146.

[25] Kojić, M., Popović, R., Karadžić, B. (1998): Sintaksonomski pregled vegetacije Srbije. Institut za biološka istraživanja Siniša Stanković, Beograd.

[26] Kozhuharov, S. (ed.) (1995): Flora Reipublicae Popularis Bulgaricae. Vol. 10. - In Aedibus Academiae Scientarum Bulgaricae, Serdicae (Sofia).

[27] Matevski, V. (ed.) (2010): Flora na Republika Makedonija 2(1). - Macedonian Academy of Sciences and Arts, Skopje.

[28] Matevski, V., Kostadinovski, M. (1998): Biserrulo-Scleranthetum dichotomae Matevski et Kostadinovski ass. nova vo vegetacijata na brdskite pasišta vo Republika Makedonija. - Godišen zbornik PMF-Biol. 51: 25-35.

[29] Matevski V., Čarni A., Kostadinovski M., Košir P., Šilc U., Zelnik I. (2008): Flora and vegetation of the Macedonian steppe. - ZRC SAZU Publishing, Ljubljana.

[30] Matevski V., Lozanovski R., Kostadinovski M. (2007): Silene-Thymetum ciliatopubescentis ass. nova in the vegetation on highland pastures in the Republic of 
Macedonia. - In: Filipovski, G., Lozanovski, R., Matevski V. (ed.) Collection of papers devoted to Academician Kiril Micevski. Macedonian Academy of Sciences and Arts, Skopje.

[31] McCune, B., Mefford, M.J. (1999): PC-ORD. Multivariate analysis of ecological data, Version 4. - MjM Design, Glenden Beach, OR.

[32] Meshinev, T., Apostolova, I., Georgiev, V., Dimitrov, V., Petrova, A., Veen, P. (2005): Grasslands of Bulgaria. Final Report of the National Grassland Inventory Project. Dragon, Sofia.

[33] Micevski, K. (1970): Astragalo-Potentilletalia, nov vegetaciski red na brdskite pasišta vo Makedonija. - Prilozi 2(2): 15-23.

[34] Micevski, K. (1971a): "Stepska" vegetacija vo Makedonija. - Godišen zbornik PMF-Biol. 23: $131-150$.

[35] Micevski, K. (1971b): Tunico-Trisetetum myrianthi Micev. ass.nov. vo vegetacijata na brdskite pasišta vo Makedonija. - Godišen zbornik PMF-Biol, 24: 59-65.

[36] Micevski, K. (1972): Helianthemo-Euphorbietum thessalae Micev. ass. nova vo vegetacijata na brdskite pasišta vo Makedonija. - Godišen zbornik PMF-Biol. 25: 149155.

[37] Micevski, K. (1977): Erysimo-Trifolietum Micev. ass.nov. vo vegetacijata na Makedonija. - Prilozi 9(1): 75-82.

[38] Micevski, K. (1978): Tipološki istražuvanja na vegetacijata na livadite i pasištata vo Maleš i Pijanec. - Macedonian Academy of Sciences and Arts, Skopje.

[39] Micevski, K. (ed.) (1985-2005): Flora na Republika Makedonija. - Macedonian Academy of Sciences and Arts, Skopje.

[40] Micevski, K., Matevski, V. (1984): Diantho-Cistetum incani Micevski et Matevski ass. nov. vo vegetacijata na SR Makedonija. - Prilozi 5(2): 11-16.

[41] Pedashenko, H., Apostolova, I., Boch, S., Ganeva, A., Janišová, M., Sopotlieva, D., Todorova, S., Ünal, A., Vassilev, K. (2013): Dry grasslands of NW Bulgarian mountains: first insight into diversity, ecology and syntaxonomy. - Tuexenia 33: 309-345.

[42] Pignatti, S. (2005): Valori di bioindicazione delle piante vascolari della flora d'Italia. Braun-Blanquetia 39: 1-98.

[43] Raunkier, C. (1934): The life forms of plants and statistical plant geography. Clarendon,Oxford.

[44] Redžić, S. (1999): The syntaxonomical differentation of the Festuco-Brometea Br.-Bl. \& R. Tx. 1943 ex Klika \& Hadač 1944 in the Balkans. - Annali di Botanica (Roma) S.N. 57: $167-180$.

[45] Rizovski, R. (1974): Cenozi na dabot ploskač (Quercus farnetto Ten.) kako zaseben vegetaciski pojas vo Dolnoto Povardarje. - Godišen zbornik na Zemjodelsko-šumarskiot fakultet na Univerzitetot, Skopje, Šumarstvo 26: 89-99.

[46] Rizovski, R. (1978): Cenoze hrasta sladuna (Quercus frainetto Ten.) u submediteranskoj zoni donjeg Povardarja. - Mitteilugen der Ostalpin-Dinarischen Gesellschaft für Vegetationskunde 14: 341-349.

[47] STATSOFT Inc. (2007): STATISTICA Data analysis system. Version 8. - StatSoft, Stuttgart.

[48] Tichý, L., Chytrý, M. (2006): Statistical determination of diagnostic species for site groups of unequal size. Journal of Vegetation Science 17: 809-818.

[49] Tichý, L., Holt, J. (2006): JUICE, program for management, analysis and classification of ecological data. - Masaryk University, Brno.

[50] Tutin, T.G., Heywood, H.V., Burges, A.N., Valentine, H.D., Walters, M.S., Webb, A.D. (eds.) (1964-1993): Flora Europaea. Vols. 1-5. - Cambridge University Press, Cambridge.

[51] Vassilev, K., Pedashenko, H., Nikolov, S.C., Apostolova, I., Dengler, J. (2011): Effect of land abandonement on the vegetation of upland semi-natural grasslands in the Western Balkan Mts., Bulgaria. - Plant Biosystems 145: 654-665. 
[52] Velchev, V. (ed.) (1982-1989): Flora Reipublicae Popularis Bulgaricae. Vols. 8 \& 9. - In Aedibus Academiae Scientarum Bulgaricae, Serdicae (Sofia).

[53] Venables, W.N., Ripley, B.D. (2002): Modern applied statistics with S. Springer, Heidelberg.

[54] Weber, H.E., Moravec, J., Theurillat, J.P. (2000): International Code of Phytosociological Nomenclature. 3rd ed. - Journal of Vegetation Science 11: 739-768.

\section{APPENDIX}

\section{Typification of new associations presented in the publication:}

Holotypus relevé of Petrorhagio haynaldianae-Chrysopogonetum grylli Matevski, Čarni, Cušterevska, Kostadinovski et Mucina ass. nova hoc loco, rel. 1 in Elect. App. Site: PrilepKozjak, date: 15. 06. 2004, Altitude: 704 m, Aspect: SE, Slope 3, Cover: 97 \%, Area: $100 \mathrm{~m}^{2}$, Coordinates: $41^{\circ} 22^{\prime} 7.07 " \mathrm{~N}, 21^{\circ} 43^{\prime} 2.93 " \mathrm{E}$.

Chrysopogon gryllus 4, Anthyllis vulneraria subsp. rubriflora 2, Convolvulus cantabrica 2, Koeleria splendens 2, Potentilla astracanica 2, Teucrium capitatum 2, Asphodeline lutea 1, Crupina vulgaris 1, Helianthemum nummularium subsp. tomentosum 1, Helianthemum salicifolium 1, Hippocrepis ciliata 1, Medicago coronata 1, Onobrychis aequidentata 1, Ononis reclinata 1, Poa bulbosa 1, Satureja montana subsp. pisidica 1, Sedum urvillei 1, Stachys iva 1, Stipa pennata 1, Achillea coarctata +, Aegilops neglecta + , Alyssum simplex + , Arabis auriculata + , Arabis sagittata + , Arenaria serpyllifolia + , Asperula aristata subsp. scabra + , Astragalus onobrychis + , Asyneuma limonifolium + , Bombycilaena erecta + , Bothriochloa ischaemum +, Bromus squarrosus + , Bupleurum apiculatum + , Centaurea stoebe subsp. australis + , Cerastium glomeratum + , Clinopodium suaveolens + , Clypeola jonthlaspi subsp. jonthlaspi + , Coronilla scorpioides + , Crepis sancta + , Echinops sphaerocephalus + , Eryngium campestre + , Erysimum diffusum + , Euphorbia myrsinites + , Euphorbia taurinensis,+ Fumana procumbens + , Galium oreophilum + , Galium verticillatum + , Hypericum rumeliacum + , Inula oculus-christi + , Leontodon crispus + , Linaria simplex + , Linum corymbulosum + , Medicago minima + , Medicago rigidula + , Melica ciliata subsp. ciliata + , Minuartia glomerata subsp. glomerata + , Minuartia hamata + , Minuartia hybrida subsp. hybrida,+ Muscari racemosum + , Myosotis incrassata +, Nigella arvensis +, Onosma visianii +, Orlaya daucorlaya +, Ornithogalum comosum + , Parentucellia latifolia + , Petrorhagia illyrica subsp. haynaldiana + , Petrorhagia prolifera + , Petrorhagia thessala + , Picris pauciflora + , Pilosella piloselloides + , Potentilla pedata + , Psilurus incurvus + , Ranunculus sprunerianus + , Rhamnus saxatilis subsp. tinctorius +, Sanguisorba minor subsp. muricata + , Scabiosa divaricata + , Scorzonera hispanica subsp. asphodeloides + , Sherardia arvensis + , Sideritis montana + , Silene radicosa + , Thesium macedonicum + , Thymelaea passerina + , Thymus striatus + , Trachynia distachya + , Tragopogon dubius subsp. dubius + , Trifolium campestre + , Trifolium scabrum + , Trigonella gladiata + , Valerianella dentata + , Verbascum herzogii + , Veronica arvensis + , Ziziphora capitata + .

Holotypus relevé of the Scorzonero-Stipetum endotrichae Matevski, Čarni, Ċušterevska, Kostadinovski et Mucina ass. nova hoc loco, rel. 54 in Elect. App. Site: Pantelejmon, above quarry, date: 01. 06. 1993, Altitude: $1130 \mathrm{~m}$, Aspect: S, Slope 25ㅇ Cover: $65 \%$, Area: $100 \mathrm{~m}^{2}$, Coordinates: $41^{\circ} 7{ }^{\prime} 56.64 " \mathrm{~N}, 21^{\circ} 48^{\prime} 1.57^{\prime \prime} \mathrm{E}$.

Chrysopogon gryllus 2, Festuca hirtovaginata 2, Scorzonera mariovoensis 2, Stachys iva 2, Stipa endotricha 2, Agropyron cristatum 1, Eryngium campestre 1, Euphorbia taurinensis 1, Helianthemum canum subsp. canum 1, Iris pumila 1, Koeleria splendens 1, Potentilla 
astracanica 1, Thymus parnassicus 1, Trinia daleschampii 1, Achillea fraasii + , Aethionema saxatile + , Alyssum doerfleri + , Anthericum liliago + , Anthyllis vulneraria subsp. rubriflora + , Arabis auriculata + , Arenaria serpyllifolia + , Asperula aristata subsp. scabra + , Astragalus mariovoense + , Asyneuma limonifolium + , Bombycilaena erecta + , Bromopsis cappadocica + , Carex liparocarpos + , Caucalis platycarpos + , Centaurea grisebachii + , Clinopodium alpinum subsp. hungaricum +, Clypeola jonthlaspi subsp. jonthlaspi + , Crupina vulgaris + , Dianthus haematocalyx subsp. haematocalyx + , Euphorbia myrsinites + , Fumana procumbens + , Galium verticillatum + , Helianthemum ummularium subsp. nuтиттularium + , Helictochloa aetolica + , Hellenocarum strictum + , Hornungia petraea + , Hypericum rumeliacum + , Juniperus oxycedrus + , Jurinea polycephala + , Lactuca perennis + , Leontodon biscutellifolius + , Linaria simplex + , Medicago medicaginoides + , Minuartia verna subsp. collina,+ Myosotis incrassata + , Neatostema apulum + , Onobrychis alba subsp. alba + , Petrorhagia thessala + , Ranunculus sprunerianus + , Rhamnus saxatilis subsp. tinctorius + , Scabiosa triniifolia + , Sedum ochroleucum + , Sideritis montana + , Silene radicosa + , Teucrium capitatum + , Thymelaea passerina + , Tragopogon pterodes + , Valerianella coronata + , Valerianella pumila + , Veronica praecox + .

Holotypus relevé of Globulario-Centaureetum grbavacensis Matevski, Čarni, Ċušterevska, Kostadinovski et Mucina ass. nova hoc loco, rel. 83 in Elect. App. Site: M. Brod-Barbaras, date: 10. 06. 2005, Altitude: $780 \mathrm{~m}$, Aspect: S, Slope $25^{\circ}$, Cover: $85 \%$, Area: $100 \mathrm{~m}^{2}$, Coordinates: $41^{\circ} 30^{\prime} 31.93^{\prime \prime N}, 21^{\circ} 15^{\prime} 45.47^{\prime \prime} \mathrm{E}$.

Anthyllis aurea 3, Centaurea grbavacensis 3, Fumana procumbens 2, Globularia cordifolia 2, Thymus skopjensis 2, Achillea ageratifolia subsp. aizoon 1, Dianthus kapinaensis 1, Eryngium wiegandii 1, Festuca hirtovaginata 1, Helianthemum canum subsp. canum 1, Linum tenuifolium 1, Matthiola fruticulosa subsp. valesiaca 1, Scorzonera austriaca 1, Stipa pulcherrima 1, Teucrium montanum 1, Alyssum stribrnyi +, Anthericum ramosum +, Anthyllis vulneraria subsp. bulgarica + , Asperula aristata subsp. scabra + , Asplenium ruta-muraria subsp. rutamuraria +, Asyneuma limonifolium +, Cerastium decalvans subsp. dollineri + , Comandra umbellata subsp. elegans + , Cytisus procumbens + , Erysimum diffusum +, Euphorbia barrelieri subsp. hercegovina +, Fraxinus ornus + , Galium oreophilum + , Haplophyllum albanicum + , Hieracium pannosum +, Hippocrepis glauca + , Inula ensifolia + , Juniperus oxycedrus + , Jurinea polycephala + , Koeleria splendens + , Leontodon crispus + , Linum austriacum +, Onosma heterophylla + , Paronychia chionaea + , Polygala vulgaris + , Quercus trojana subsp. trojana + , Salvia ringens + , Saponaria bellidifolia + , Saxifraga federici-augusti subsp. grisebachii + , Seseli rigidum + , Thalictrum minus subsp. minus + , Thymelaea passerina + , Vincetoxicum hirundinaria subsp. nivale + , Viola herzogii + .

Holotypus relevé of Astragalo-Helianthemetum marmorei Matevski, Čarni, Cušterevska, Kostadinovski et Mucina ass. nova hoc loco, rel. 103 in Elect. App. Site: Prilep-Pletvar, date: 16. 06. 2004, Altitude: $1083 \mathrm{~m}$, Aspect: S, Slope $30^{\circ}$, Cover: $65 \%$, Area: $100 \mathrm{~m}^{2}$, Coordinates: $41^{\circ} 22^{\prime} 21.81 " \mathrm{~N}, 21^{\circ} 39^{\prime} 21.14 " \mathrm{E}$.

Anthyllis aurea 3, Astragalus sericophyllus 3, Fumana procumbens 3, Helianthemum marmoreum 3, Thymus parnassicus 3, Achillea ageratifolia subsp. aizoon 2, Agropyron cristatum 2, Stipa pulcherrima 2, Anthyllis vulneraria subsp. rubriflora 1, Bromopsis riparia 1, Festuca hirtovaginata 1, Linum hirsutum subsp. hirsutum 1, Micromeria cristata subsp. kosaninii 1, Potentilla astracanica 1, Alkanna pulmonaria + , Allium bornmulleri + , Alyssum corymbosoides +, Asperula aristata subsp. scabra +, Asperula purpurea +, Asyneuma limonifolium +, Carex liparocarpos + , Centaurea marmorea + , Chrysopogon gryllus +, Clinopodium alpinum subsp. hungaricum + , Cruciata laevipes + , Dianthus haematocalyx subsp. 
haematocalyx + , Echinops ritro + , Erodium absinthoides + , Euphorbia barrelieri subsp. thessala + , Euphorbia myrsinites + , Galium oreophilum + , Helianthemum nummularium subsp. tomentosum + , Hieracium pannosum + , Hippocrepis glauca + , Hypericum rumeliacum + , Iris pumila + , Juniperus oxycedrus + , Jurinea polycephala + , Koeleria splendens + , Leontodon crispus + , Linaria simplex + , Matthiola fruticulosa subsp. valesiaca + , Melica ciliata subsp. ciliata,+ Minuartia setacea + , Muscari racemosum + , Odontites glutinosa + , Onosma heterophylla + , Ornithogalum comosum + , Paronychia macedonica subsp. macedonica + , Pilosella piloselloides + , Polygala vulgaris + , Scorzonera austriaca + , Seseli vandasii + , Stachys iva + , Teucrium montanum +, Thesium macedonicum +, Thymelaea passerina +, Thymus striatus + , Vincetoxicum hirundinaria subsp. nivale + , Viola herzogii + .

Electronic Appendix: The analytical phytosociological table of the four new associations of the Macedonian dry grasslands. * Life forms: $\mathrm{P}$ - phanerophyte, $\mathrm{Ch}-$ chamaephyte, $\mathrm{H}-$ hemicriptophyte, $\mathrm{G}$ - geophyte, $\mathrm{T}$ - therophyte. ${ }^{* *}$ Geoelements: 1.1 - Balkan (s. lat.), 1.2 South Balkan, 1.3 - Scardo-Pindian, 1.4 - Macedonian (sub) endemic, 1.5 - Balkan-Apennine, 1.6 - South Balkan-Asia Minor, 1.7 - South Balkan-Caucasian 2 - Steno-Mediterranean, 3 Eury-Mediterranean, 4 - Mediterranean-montane, 5 - Eurasian, 6 - Atlantic, 7 - OrophilousSouth European, 8 - Boreal, 9 - Cosmopolitan; H - holotype; Associations: P - PetrorhagioChrysopogonetum grylli, S - Scorzonero-Stipetum endotrichae, G - Globulario-Centaureetum grbavacensis, A - Astragalo-Helianthemetum marmorei.

\section{Geographic and sampling-relevant data in the analytical Electronic Appendix: Each entry consists of the following: Relevé number, locality, area of relevés $\left(m^{2}\right)$, cover \%, slope in degree, aspect, altitude in m, coordinates: latitude and longitude, and date:}

1: Prilep-Kozjak, 100, 97, 3, SE, 704, 41 ${ }^{\circ} 22^{\prime} 7.07^{\prime N}, 21^{\circ} 43^{\prime 2} .93 " \mathrm{E}, 15.06 .2004 ;$ 2: Prilep-Kozjak, 100, 98, 3, SE, 715,

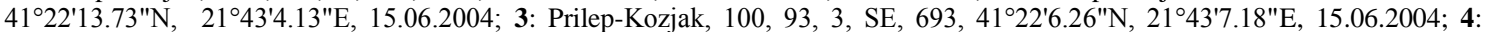

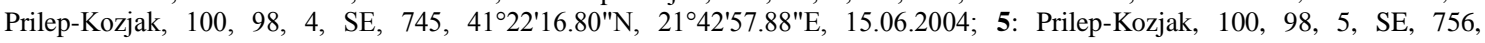
$41^{\circ} 22^{\prime} 16.25^{\prime \prime N}, 21^{\circ} 42^{\prime} 51.55^{\prime \prime E}, 15.06 .2004 ;$ 6: Prilep-Kozjak, 100, 97, 2, S, 666, 41 ${ }^{\circ} 22^{\prime} 49.97 " \mathrm{~N}, 2^{\circ} 43^{\prime} 52.20^{\prime \prime} \mathrm{E}, 22.06 .2004$; 7:Prilep-Kozjak, 100, 97, 3, SE, 680, 41 ${ }^{\circ} 22^{\prime} 49.85^{\prime \prime N}, 21^{\circ} 43^{\prime} 46.04 " E$, 22.06.2004; 8: Prilep-Kozjak, 100, 99, 3, S, 682,

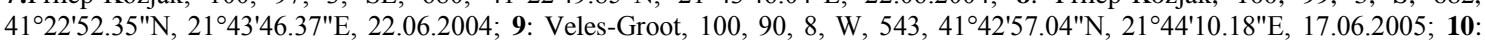

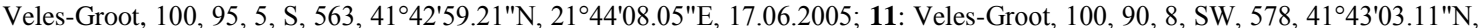

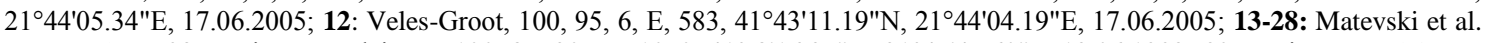
2007: Tab. 1; 29: Bešište-Pantelejmon, 100, 85, 30, W, 1050, 41 ${ }^{\circ} 8^{\prime} 16.35^{\prime \prime N}, 2^{\circ} 47^{\prime} 45.60 " \mathrm{E}, 13.06 .1992$; 30: Bešište-Pantelejmon, $100,80,25, \mathrm{~W}, 1040,41^{\circ} 8^{\prime} 15.86^{\prime \prime} \mathrm{N}, 21^{\circ} 47^{\prime} 42.43^{\prime \prime E}, 13.06 .1992 ; 31$ : Bešište-Pantelejmon, 100, 80, 30, W, 1090, 41 8'13.86"N,

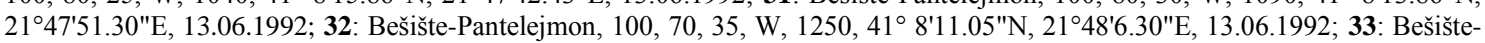
Pantelejmon, 100, 80, 30, NW, 1300, 41 ${ }^{\circ} 8^{\prime} 14.35^{\prime \prime} \mathrm{N}, 21^{\circ} 48^{\prime} 12.91^{\prime \prime E}, 13.06 .1992 ; 34$ : Bešište-Pantelejmon, 100, 90, 35, W, 1280, $41^{\circ} 8^{\prime} 13.83^{\prime \prime N}, 21^{\circ} 48^{\prime} 10.00^{\prime \prime E}, 13.06 .1992 ; 35$ : Bešište-Pantelejmon, 100, 70, 30, W, 1130, 41 ${ }^{\circ} 8^{\prime} 17.34^{\prime \prime} \mathrm{N}, 21^{\circ} 47^{\prime} 57.92^{\prime \prime E}$, 13.06.1992; 36: Bešište-Pantelejmon, 100, 80, 35, W, 1210, 41ํ 8'17.05"N, 21 ${ }^{\circ} 48^{\prime} 5.52^{\prime \prime E}, 13.06 .1992$; 37: Vitolište-Gola Srka, 100,

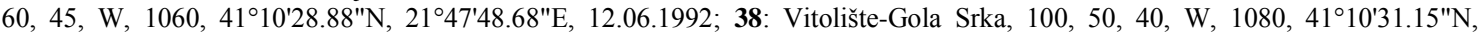

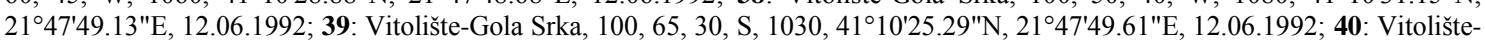

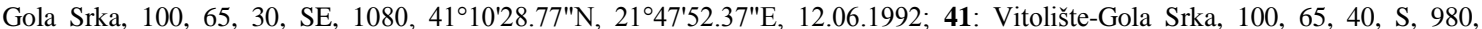

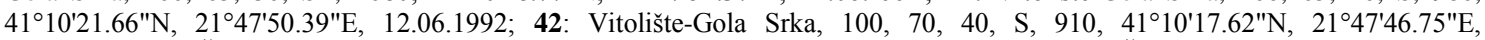
12.06.1992; 43: Živovo, 100, 75, 30, N, 1220, 41 ${ }^{\circ} 13^{\prime} 8.78^{\prime \prime} \mathrm{N}, 21^{\circ} 47^{\prime} 53.50 " \mathrm{E}, 03.06 .1993 ; 44:$ Živovo, 100, 75, 30, N, 1220,

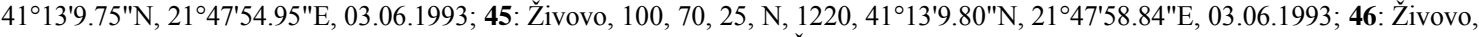

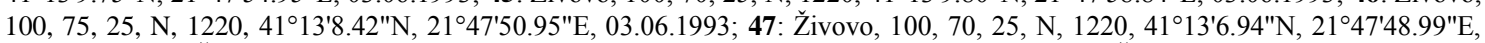
03.06.1993; 48: Živovo, 100, 60, 15, NE, 1200, 41 ${ }^{\circ} 13^{\prime} 6.95^{\prime \prime} \mathrm{N}, 2^{\circ} 47^{\prime} 57.13 " \mathrm{E}, 03.06 .1993$; 49: Živovo, 100, 55, 10, NE, 1210,

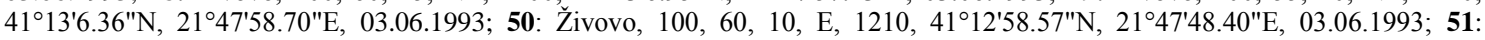
Pantelejmon, above quarry, $100,65,30$, SW, $1100,41^{\circ} 8^{\prime} 3.91^{\prime \prime} \mathrm{N}, 2^{\circ} 47^{\prime} 47.46 " \mathrm{E}, 01.06 .1993 ;$ 52: Pantelejmon,above quarry, 100 ,

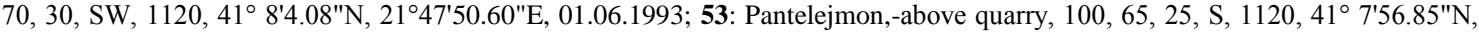

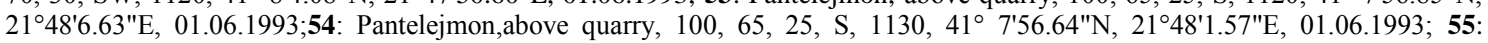

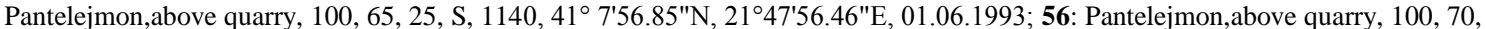
$30, \mathrm{~S}, 1080,41^{\circ} 7^{\prime} 39.05^{\prime \prime} \mathrm{N}, 21^{\circ} 48^{\prime} 24.22^{\prime \prime E}, 01.06 .1993 ; 57$ : Pantelejmon, above quarry, 100, 75, 25, S, 1100, 41 ${ }^{\circ} 74.23$ "N,

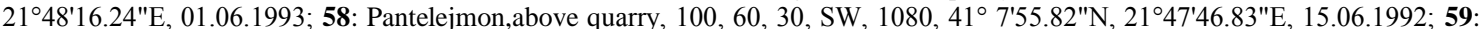
Pantelejmon,above quarry, 100, 55, 30, SW, 1110, 41 ${ }^{\circ} 7^{\prime} 59.83^{\prime \prime} \mathrm{N}, 2^{\circ} 47^{\prime} 49.11^{\prime \prime} \mathrm{E}, 15.06 .1992 ; 60$ : Pantelejmon, above quarry, 100 , 60, 30, SW, 1110, $41^{\circ} 7^{\prime} 55.08^{\prime \prime N}, 2^{\circ} 47^{\prime} 49.76 " \mathrm{E}, 15.06 .1992 ;$ 61: Pantelejmon, above quarry, 100, 60, 30, SW, 1060, 41 ${ }^{\circ} 7^{\prime} 48.999^{\prime \prime} \mathrm{N}$,

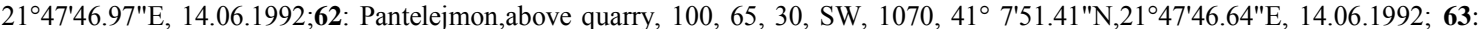
Mariovo-Sekulova Tumba, 100, 60, 40, S, 970, 41 ${ }^{\circ} 6^{\prime} 10.95 " N, 21^{\circ} 47^{\prime} 58.57 " \mathrm{E}, 18.06 .1995$; 64: Mariovo-Sekulova Tumba, 100, 65,

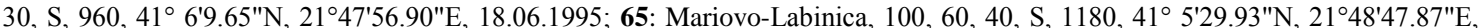
17.06.1995; 66: Mariovo-Labinica, 100, 50, 40, S, 1170, 41 ${ }^{\circ} 5^{\prime} 35.00^{\prime \prime} \mathrm{N}, 21^{\circ} 48^{\prime} 42.89 " \mathrm{E}, 17.06 .1995$; 67: Mariovo-Labinica, 100, 60, 


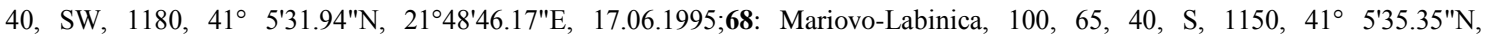

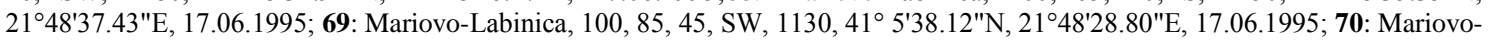
Labinica, 100, 65, 40, S, 1160, 41 ${ }^{\circ} 5^{\prime} 36.06^{\prime \prime} \mathrm{N}, 2^{\circ} 48^{\prime} 38.86 " \mathrm{E}, 17.06 .1995 ;$ 71: Mariovo-Labinica, 100, 80, 40, SW, $1160,41^{\circ}$

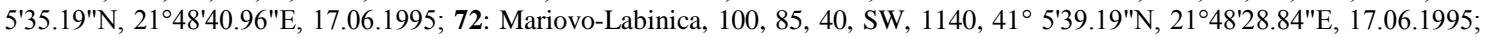
73: Mariovo-Toplik, 100, 85, 25, W, 1160, 41 ${ }^{\circ} 2^{\prime} 33.07^{\prime \prime N}, 21^{\circ} 48^{\prime} 34.13 " \mathrm{E}, 19.06 .1995 ;$ 74: Mariovo-Toplik, 100, 80, 35, W, 1140,

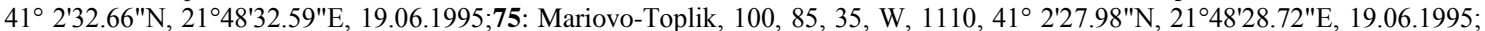
76: Skopje-Kozjak, 100, 80, 15, SW, 1072, 41 ${ }^{\circ} 53^{\prime} 21.02^{\prime \prime N}, 21^{\circ} 13^{\prime 2} 24.00 " E, 08.07 .2006$; 77: Skopje-Kozjak, 100, 85, 35, W, 1055,

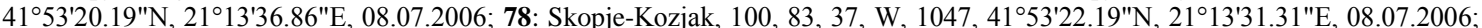

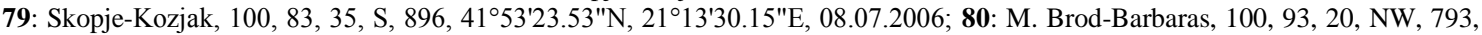

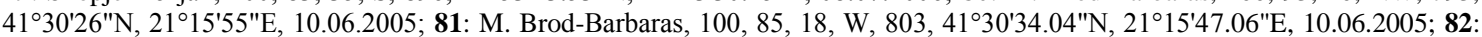
M. Brod-Barbaras, 100, 88, 20, W, 759, 41 ${ }^{\circ} 30^{\prime} 29.79^{\prime \prime} \mathrm{N}, 2^{\circ} 1^{\circ} 5^{\prime} 42.76^{\prime \prime} \mathrm{E}, 10.06 .2005 ; 83$ : M. Brod-Barbaras, 100, 85, 25, S, 780,

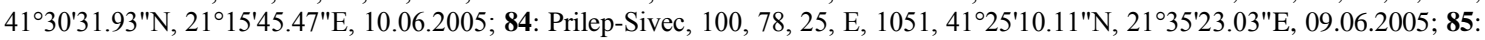

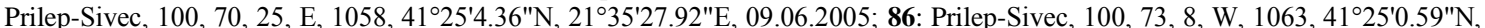

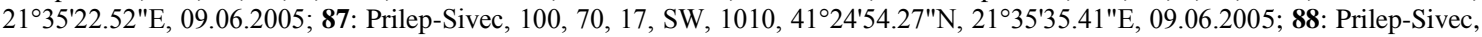

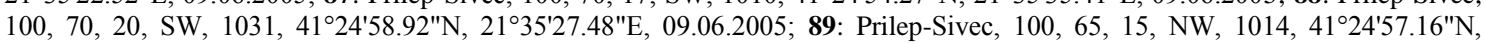

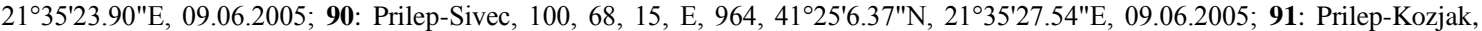

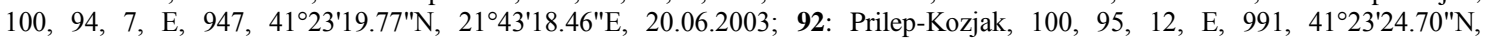

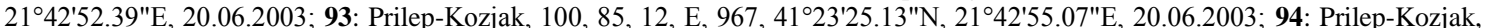

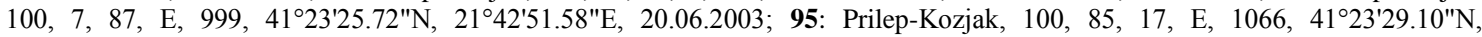
21 42'44.04"E, 20.06.2003;96: Prilep-Kozjak, 100, 90, 15, E, 1193, 41²3'33.28"N, 2142'29.17"E, 20.06.2003; 97: Prilep-Kozjak,

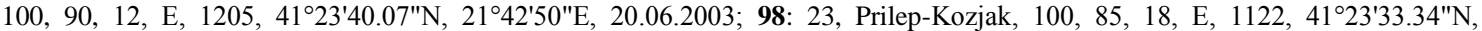

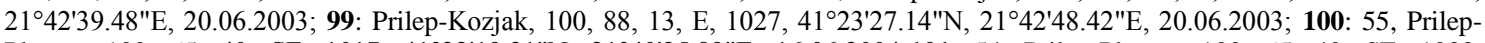
Pletvar, 100, 65, 40, SE, 1017, 41 $22^{\prime} 19.21^{\prime \prime N}, 2^{\circ} 40^{\prime} 25.89^{\prime \prime E}, 16.06 .2004 ; 101:$ 54, Prilep-Pletvar, 100, 65, 40, SE, 1033,

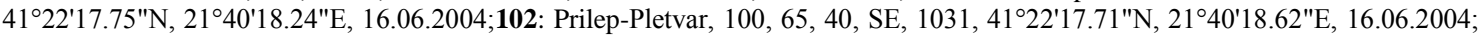
103: Prilep-Pletvar, 100, 65, 30, S, 1083, 41 ${ }^{\circ} 22^{\prime} 21.81^{\prime \prime N}, 21^{\circ} 39^{\prime} 21.14 " \mathrm{E}, 16.06 .2004 ; 104$ : Prilep-Pletvar, 100, 65, 35, S, 1073,

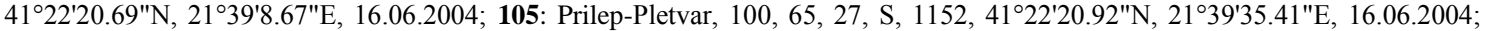

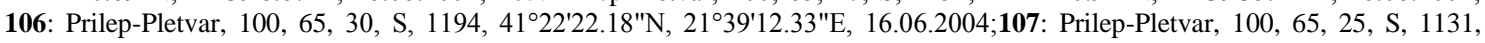
$4^{\circ} 22^{\prime} 25.45^{\prime \prime N}, 21^{\circ} 39^{\prime} 9.50 " \mathrm{E}, 16.06 .2004 ;$ 108: Prilep-Pletvar, 100, 70, 25, S, 1077, 41²2'21.49"N, 21³9'5.74"E, 16.06.2004; 109: Prilep-Pletvar, 100, 70, 20, S, 1063, 41²2'19.74"N, 21³9'8.98"E, 16.06.2004.

\section{Other species:}

Adonis flammea 2: +, 3: +, 4: +; Aegilops comosa subsp. heldreichii 9: +, 10: +, 11: +; Aegilops triuncialis 9: +, 10: +, 11: +; Agrimonia eupatoria 8: +; Allium flavum 101: +, 107: +; Allium paniculatum $3:+, 7:+, 12:+;$ Althaea hirsuta $5:+, 7:+;$ Alyssum montanum 80: +, 82: +, 83: +; Amelanchier ovalis 85: +, 89: +; Anemone nemorosa $1:+, 2:+, 3:+;$ Anemone pavonina $4:+, 5:+$; Anthemis arvensis $12:+, 86:+;$ Anthemis cretica $73:+, 74:+, 90:+;$ Anthemis ruthenica $7:+;$ Aphanes arvensis $1:+, 4:+;$ Arenaria leptoclados 3: $+, 4:+, 8:+;$ Artemisia campestris $90:+;$ Asterolinon linum-stellatum $2:+, 4:+, 5:+;$ Bupleurum commutatum $51:+$, 55: +; Bupleurum pachnospermum 9: +, 12: +; Buxus sempervirens 76: +, 79: +; Campanula lingulata 77: +, 79: +; Carex caryophyllea 76: +, 77: 1, 80: +; Carthamus lanatus 7: +; Centaurium erythraea 76: +, 77: +, 79: +; Cerastium rectum subsp. petricola 50: +, 51: +, 57: +; Chondrilla juncea 7: +; Colchicum doerfleri 50: +, 58: +, 59: +; Cotoneaster nebrodensis 30: +, 36: +; Crepis foetida subsp. rhoedifolia 8: +, 9: +; Crepis pulchra 38: +; Crupina crupinastrum 6: +; Cynodon dactylon 3: +; Cynosurus echinatus 8: +; Dianthus gracilis subsp. armeroides 8: +; Echinaria capitata 6: +, 7: +, 8: +; Echium vulgare 8: +; Edraianthus graminifolius 73: +, 74: +, 75: +; Epipactis atrorubens 73: +, 74: +, 75: +; Erodium cicutarium 3: +, 9: +, 11: +; Euphorbia falcata $6:+, 7:+;$ Euphorbia helioscopia 7: +, 8: +; Euphrasia salisburgensis 107: +; Ferulago sylvatica 75: +; Genista carinalis $73:+$; Genista sagittalis 95: +, 97: 1, 98: 1; Genista sessilifolia 30: +, 31: +, 51: +; Geranium purpureum 55: +; Geranium sanguineum 73: +, 75: +; Goniolimon tataricum 29: +, 32: +, 35: +; Haplophyllum suaveolens $8:+, 93:+, 95:+;$ Hypericum perforatum 8: +, 6: +, 7: +; Iris reichenbachii 11: +, 12: +; Lathyrus cicera 3: +, 11: +, 86: +; Legousia hybrida 11: +, 12: +; Lomelosia argentea 90: +; Lomelosia brachiata 5: +, 8: +, 88: +; Melilotus neapolitana 91: +; Odontites luteus 77: +, 83: +, 82: +; Paliurus spina-christi 9: +, 11: +; Pinus nigra subsp. pallasiana 73: $+, 74:+, 75:+;$ Pistacia terebinthus $11:+, 41:+;$ Plantago lanceolata $3:+, 8:+;$ Plantago subulata 102: +; Polygala major 73: +, 75: +; Polygala monspeliaca 1: +, 8: +; Polygala oxyptera 103: +, 105: +; Pontechium maculatum 34: +, 33: +; Pulsatilla halleri subsp. rhodopaea 84: +, 85: +; Ranunculus oreophilus subsp. balcanicus $73:+, 75:+$; Salvia argentea 100: $+, 105:+, 106:+$; Scabiosa rotata 10: $+, 11:+, 60:+;$ Scutellaria orientalis subsp. pinntifida $31:+;$ Senecio leucanthemifolius subsp. vernalis 64: +, 65: +; Sesleria rigida 73: +, 74: +, 75: +; Silene bupleuroides subsp. staticifolia 58: +, 87: +, 90: +; Silene saxifraga 84: +, 86: +, 90: +; Stachys recta 77: +; Taeniatherum caput-medusae 9: +, 10: +; Thymus sibthorpii 86: +; Torilis leptophylla 8: +, 6: +; Tragopogon pratensis 9: +; Trifolium angustifolium 5: +; Trifolium arvense 12: +; Viola kitaibeliana $9:+, 11:+, 12:+$. 